Фармацевтична технологія, біофармація, гомеопатія

Pharmaceutical technology, biopharmacy, homeopathy

Рекомендована д. фармац. наук, проф. Т. А. Грошовим

УДК 614.8:[615.014.2:546.212.002.65]

\title{
ОСОБЛИВОСТІ ОТРИМАННЯ ВОДИ ДЛЯ ВИГОТОВЛЕННЯ ЛІКАРСЬКИХ ЗАСОБІВ В УМОВАХ НАДЗВИЧАЙНИХ СИТУАЦІЙ
}

\author{
๑П. В. Олійник, Б. П. Громовик \\ Львівський національний медичний університет імені Данила Галицького
}

\begin{abstract}
Резюме: проведено аналіз методів отримання і застосування води для екстемпорального виготовлення лікарських засобів в лікарняних аптеках, розгорнутих у пристосованих приміщеннях в умовах надзвичайних ситуацій мирного і воєнного часу. Показано можливість застосування води очищеної для виготовлення парентеральних лікарських засобів, очних крапель, розчинів нестійких препаратів і лікарських засобів для новонароджених, а води свіжопрокип'яченої - для виготовлення усіх інших рідких ЛЗ, які не потребують асептичних умов виготовлення або стерилізації у тих випадках, коли отримання води для ін'єкцій в аптеках, розгорнутих у пристосованих приміщеннях в умовах надзвичайних ситуацій, є неможливим.
\end{abstract}

Ключові слова: надзвичайна ситуація, аптека, вода для ін'єкцій, вода очищена, лікарський засіб.

Вступ. Практика останніх років наочно показує важливість захисту населення і території держави при надзвичайних ситуаціях (HC) різного характеру [1]. Сучасна техногенно-екологічна і соціально-політична обстановка (ризики виникнення землетрусу, проведення антитерористичної операції та введення режиму НC на території Донецької і Луганської областей) свідчить про високу імовірність виникнення НС природного, техногенного і соціальнополітичного походження із значною кількістю постраждалого населення, наслідки якого існуюча інфраструктура регіональної системи організації охорони здоров'я буде неспроможна усунути наявними силами і засобами.

В умовах ліквідації наслідків НС необхідним $€$ розгортання лікарняних аптечних закладів (ЛАЗ) у пристосованих приміщеннях (ПП) поза зоною лиха [2]. Надання медичної допомоги і лікування постраждалого населення потребуватиме значної кількості лікарських засобів (ЛЗ) екстемпорального виготовлення. В процесі їх виготовлення особливе значення має вода, яка використовується як розчинник або допоміжна речовина. Сучасні методи отримання води для виготовлення ЛЗ потребують високотехнологічного обладнання і приміщень високого ступеня чистоти. Розгортання ЛАЗ має здійснюватись у ПП (будинках відпочинку, готелях, школах тощо) в умовах гострого дефіциту часу, що ставить під сумнів можливість дотримання усіх вимог Державної Фармакопеї України (ДФУ) щодо води для виготовлення ЛЗ [3].

Мета роботи - аналіз і визначення можливих методів отримання води для екстемпорального виготовлення ЛЗ у ЛАЗ, розгорнутих у ПП в умовах НС мирного і воєнного часу.

Методи дослідження. У процесі дослідження використовували методи спостереження та узагальнення, синтезу і формалізації, контентаналізу. Предметом дослідження була організація роботи ЛАЗ із екстемпорального виготовлення ЛЗ в умовах ліквідації наслідків НС.

Результати й обговорення. В стаціонарних умовах аптеки отримують воду для виготовлення ЛЗ із питної води шляхом дистиляції або іншим способом за допомогою відповідних технічних пристроїв. Для ЛАЗ, розгорнутих в умовах ліквідації наслідків НС, вибір способу отримання води, придатної для виготовлення ЛЗ, залежатиме від низки чинників [4]:

- медичної, хімічної, бактеріологічної, санітарно-гігієнічної та інших видів ситуацій, які можуть скластись у зоні НС;

- наявності: достатньої кількості джерел води, допущеної органами санітарно-протиепідемічного нагляду в якості питної; безперебійного електропостачання; відповідних технічних засобів для отримання достатньої кількості води належної якості.

Аналіз вимог до води, призначеної для виготовлення ЛЗ, свідчить, що ДФУ регламентує застосування 5 її видів різного ступеня очищення. До них належать:

- вода високоочищена - для приготування ЛЗ, які потребують застосування води підвищеної біологічної якості;

- вода для ін'єкцій «in bulk» - для приготування парентеральних Л3;

- вода для ін'єкцій стерильна - для розведення субстанцій або ЛЗ для парентерального застосування перед використанням;

ISSN 2312-0967. Фармацевтичний часопис. 2015. № 1 
Фармацевтична технологія, біофармація, гомеопатія

Pharmaceutical technology, biopharmacy, homeopathy

- вода очищена «in bulk» - для виготовлення ЛЗ, крім тих, які мають бути стерильними й апірогенними;

- вода очищена в контейнерах - для виготовлення ЛЗ, крім тих, які мають бути стерильними й апірогенними.

Для порівняння - Державна Фармакопея Російської Федерації (2012р.) регламентує застосування лише 2 видів води: вода для ін'єкцій і вода очищена.

Вимоги ДФУ щодо ступеня очистки води, призначеної для виготовлення ЛЗ, є достатньо високими і стосуються питомої електропровідності, вмісту хімічних речовин та мікроорганізмів. Основним показником ступеня очистки води $€$ загальне іонне забруднення, яке визначають за показником питомої електропровідності та вмістом аеробних мікроорганізмів.

Згідно з вимогами ДФу, показник питомої електропровідності для води очищеної повинен становити не більше 4,3 мкСм • $\mathrm{CM}^{-1}$, а води для ін'єкцій «in bulk» не більше 1,1 мкСм • $\mathrm{cm}^{-1}$. Питома електропровідність води для ін'єкцій стерильної повинна складати не більше 5 мкСм·см-1 для контейнерів із номінальним об'ємом понад 10 мл і не більше 25 мкСм·см' ${ }^{-1}$ для контейнерів із номінальним об'ємом 10 мл або менше. Як свідчить досвід ліквідації відомих НС, дотримання усіх вимог ДФУ щодо отримання води для виготовлення ЛЗ в ЛАЗ, розгорнутих в ПП в умовах ліквідації наслідків НС, $€$ практично неможливим [5].

Достатньо сумнівною є можливість забезпечення екстемпорального виготовлення ЛЗ в умовах НС шляхом доставки води, яка відповідає вимогам ДФу, із стаціонарних аптек і фармацевтичних підприємств, розміщених поза зоною НС. Проте, як відомо, вода для виготовлення ЛЗ, має термін придатності не більше 24 годин, а доставка їі значної кількості в зону НС потребує відповідних для транспортування і зберігання води контейнерів, спеціального транспорту і достатньої кількості часу. Проте, якщо очищення води безпосередньо в ЛАЗ неможливе, то необхідно організувати їі доставку 3 інших аптек, розміщених за межами зони $\mathrm{HC}$.

Проблему отримання води належної якості для екстемпорального виготовлення ЛЗ можна вирішити за наявності сучасних, достатньо портативних і потужних апаратів, які дозволяють отримувати воду високоочищену, воду для ін'єкцій і воду очищену методами іонного обміну, зворотного осмосу, мікро-, ультра- і нанофільтрації, електродіалізу та іншими методами, що на сучасному рівні оснащення більшості аптек $€$ практично неможливим.

Відомо, що під час ліквідації наслідків НС мирного і воєнного часу, в умовах масового надхо- дження до лікарняного закладу значної кількості поранених і постраждалих, Положенням про роботу військових аптек дозволено застосування води очищеної для виготовлення розчинів для парентерального введення, очних крапель та розчинів нестійких препаратів. Свіжопрокип'ячену воду дозволено використовувати для виготовлення усіх інших рідких ЛЗ [6].

Тому у тих випадках, коли отримання води для ін'єкцій в ЛАЗ, розгорнутих в ПП в умовах ліквідації НС, неможливе, старшим медичним керівником в зоні ліквідації наслідків НС має бути прийняте рішення і виданий письмовий дозвіл на застосування води очищеної для виготовлення парентеральних ЛЗ, очних крапель, розчинів нестійких препаратів і ЛЗ для новонароджених, а води свіжопрокип'яченої - для виготовлення усіх інших рідких ЛЗ, які не потребують асептичних умов виготовлення або стерилізації.

Отримання води для виготовлення ЛЗ в ЛАЗ в умовах ліквідації наслідків НС потребує значну кількість питної води. 3 цією метою необхідно використовувати усі діючі їі джерела: системи централізованого водопостачання, артезіанські свердловини, колодязі тощо, за умови, що вона відповідатиме вимогам Державних санітарних правил і норм «Гігієнічні вимоги до води питної, призначеної для споживання людиною» [7]. При відсутності стаціонарних джерел водопостачання ЛАЗ необхідно створювати запаси питної води шляхом її доставки в автомобільних цистернах з інших територій. Цистерни з водою повинні бути замкнені і знаходитись під охороною. Запас води у цистернах освіжають не рідше ніж через дві доби.

На якість води очищеної та води для ін'єкцій впливає вихідний склад питної води, умови отримання і зберігання води. Щодо річкової або криничної води, то вона потребує попередньої водопідготовки, оскільки містить як розчинені, так і механічні та колоїдно-суспендовані домішки: органічні речовини, аміак, солі, що надають воді твердості, та інші речовини. Методи очищення залежать від характеру домішок, які містяться в воді. Механічні домішки можна видаляти відстоюванням 3 наступним зливанням води 3 осаду (декантацією) або фільтруванням. Для цього використовують фільтри, заповнені активованим вугіллям і кварцевим піском. Ємності мають бути оснащені пристроєм для вводу, виводу і розподілу води всередині фільтра. Фільтри можуть бути одношаровими (наприклад, тільки шар вугілля) або двошаровими (вугілля і кварцевий пісок). Висота завантаження коливається залежно від кількості суспендованих частинок і бажаного промивального ефекту. При

ISSN 2312-0967. Pharmaceutical review. 2015. № 1 
Фармацевтична технологія, біофармація, гомеопатія Pharmaceutical technology, biopharmacy, homeopathy

використанні питної води, що містить велику кількість органічних речовин (головним чином, у районах, де джерела води знаходяться на глинистому грунті), у т. ч. й мікробні тіла, перед дистиляцією для їх руйнування до 100 л цієї води додають у вигляді розчину 2,5 г калію перманганату (або 1\% розчин калію перманганату 25 мл на 10 л води), перемішують і залишають відстоюватись на 6-8 годин [6].

Висновки. 1. Встановлено, що для ЛАЗ, розгорнутих в умовах ліквідації наслідків НС, вибір способу отримання води придатної для виготовлення Лз буде залежати від різних чинників: медичної, хімічної, бактеріологічної, санітарногігієнічної та інших видів ситуації, яка може скластись у зоні НС; наявності достатньої кількості джерел води, допущеної органами санітарнопротиепідемічного нагляду в якості питної; наявності безперебійного електропостачання; наявності відповідних аквадистиляторів або інших технічних засобів для отримання достатньої кількості води належної якості.

2. Обгрунтовано можливість застосування води очищеної для виготовлення парентеральних ЛЗ, очних крапель, розчинів нестійких препаратів і ЛЗ для новонароджених, а води свіжопрокип'яченої - для виготовлення усіх інших рідких ЛЗ, які не потребують асептичних умов виготовлення або стерилізації у тих випадках, коли отримання води для ін'єкцій в аптеках розгорнутих в ПП в умовах ліквідації наслідків НС неможливе.

\title{
Література
}

1. Національна доповідь про стан техногенної та природної безпеки в Україні. - Київ : МНС України. - 2012. - 359 с.

2. Закон України від 08.06.2000 № 1809-ІІІ «Про захист населення і територій від надзвичайних ситуацій техногенного і природного характеру» // Відомості Верховної Ради України, 2000. - № 40. - С. 337.

3. Організація роботи аптек в умовах надзвичайних ситуацій: метод. реком. (98.12/302.12) / Т. Г. Калинюк, П. В. Олійник, Б. П. Громовик, Є. Є. Євстратьєв. К., 2012. -21 c.

4. Олійник П.В. Екстремальна медицина: Організація роботи аптек в умовах надзвичайних ситуацій: підручник / П. В.Олійник, Т. Г. Калинюк; за ред. Т. Г. Калиню-

ка. - К. : Медицина, 2010. - 448 с.

5. Коротких П. П. Особенности организации медицинской помощи при массовых санитарных потерях во время землетрясения в Армении / П. П. Коротких, Л. А. Нянин, В. М. Шачкин // Военно-медицинский журнал. - 1989. - № 12. - С. 19-20.

6. Положення про роботу військових аптек. - К., 2000. $-449 \mathrm{c}$.

7. Державні санітарні правила і норми «Гігієнічні вимоги до води питної, призначеної для споживання людиною» (ДСанПіН 2.2.4-171-10).- [Електронний ресурс]. - Режим доступу: http://zakon2.rada.gov.ua/laws/ show/ z0452-10

\section{ОСОБЕННОСТИ ПОЛУЧЕНИЯ ВОДЫ ДЛЯ ИЗГОТОВЛЕНИЯ ЛЕКАРСТВЕННЫХ СРЕДСТВ В УСЛОВИЯХ ЧРЕЗВЫЧАЙНЫХ СИТУАЦИЙ}

\section{П. В. Олийнык, Б. П. Громовик}

Львовский национальный медицинский университет имени Данила Галицкого

\begin{abstract}
Резюме: проведен анализ методов получения и применения воды для экстемпорального изготовления лекарственных средств в больничных аптеках, развернутых в приспособленных помещениях в условиях чрезвычайных ситуаций мирного и военного времени. Обоснована возможность применения воды очищенной для изготовления парентеральных лекарственных средств, глазных капель, растворов неустойчивых препаратов и ЛС для новорожденных, а воды свежепрокипяченной - для изготовления всех жидких ЛС, не требующих асептических условий изготовления или стерилизации в тех случаях, когда получение воды для инъекций в аптеках, развернутых в приспособленных помещениях в условиях чрезвычайных ситуаций, невозможно.
\end{abstract}

Ключевые слова: чрезвычайная ситуация, аптека, вода для инъекций, вода очищенная, лекарственное средство.

ISSN 2312-0967. Фармацевтичний часопис. 2015. № 1 


\section{FEATURES OF WATER PRODUCTION FOR MAKING DRUG IN EMERGENCY SITUATIONS}

\section{P. V. Oliynyk, B. P. Hromovyk}

Lviv National Medical University by Danylo Halytsky

Summary: the analysis methods for the preparation and use of water for the extemporaneous preparation of medicines in hospital pharmacies deployed in adapted premises in emergency situations in peacetime and wartime. The possibility to use purified water manufacturing parenteral drugs, eye drops, solutions unstable drugs and drugs to newborns and recently boiled water - for the manufacture of liquid medicines that do not require aseptic manufacture or sterilization in those cases where the production of water for injection in pharmacies deployed in the adapted premises in emergencies impossible.

Key words: emergency situation, pharmacy, water for injection, purified water, medicines. 